\title{
Cytotoxicity of Selenium-Enriched Chinese Kale (Brassica oleracea var. alboglabra L.) Seedlings Against Caco-2, MCF-7 and HepG2 Cancer Cells
}

\author{
Vijitra Luang-In ${ }^{1, *}$, Worachot Saengha ${ }^{1}$, Benjaporn Buranrat ${ }^{2}$, Anut Chantiratikul ${ }^{3}$, Nyuk Ling Ma ${ }^{4}$
}

Vijitra Luang-In',*, Worachot Saengha ${ }^{1}$, Benjaporn Buranrat ${ }^{2}$, Anut Chantiratikul ${ }^{3}$, Nyuk Ling $\mathrm{Ma}^{4}$

'Natural Antioxidant Innovation Research Unit, Department of Biotechnology, Faculty of Technology, Mahasarakham University, Khamriang, Kantarawichai, Maha Sarakham 44150, THAILAND.

${ }^{2}$ Faculty of Medicine, Mahasarakham University, Muang, Maha Sarakham 44000, THAILAND.

${ }^{3}$ Animal Feed Resources and Animal Nutrition Research Unit, Division of Animal Science,

Faculty of Technology, Mahasarakham

University, Maha Sarakham 44150,

THAILAND.

${ }^{4}$ Faculty of Science and Marine Environment Universiti Malaysia Terengganu, 21030, Kuala Nerus, Terengganu, MALAYSIA.

\section{Correspondence}

\section{Vijitra Luang-In}

Natural Antioxidant Innovation Research Unit, Faculty of Technology, Mahasarakham University, Khamriang Sub-district,

Kantarawichai District, Maha Sarakham 44150, THAILAND

Phone No: +66 (0)43754085 ext. 1833

E-mail: vijitra.|@msu.ac.th

History

- Submission Date: 12-02-2020;

- Review completed: 03-03-2020;

- Accepted Date: 03-04-2020.

DOI : 10.5530/pj.2020.12.99

Article Available online

http://www.phcogj.com/v12/i4

Copyright

(C) 2020 Phcogj.Com. This is an openaccess article distributed under the terms of the Creative Commons Attribution 4.0 International license.

\begin{abstract}
Background: The Selenium-enriched Chinese kale (Brassica oleracea var. alboglabra L.) seedlings (Se-KS) have been known for its antioxidant activities, however its cytotoxic effects on various cancer cells are yet to be reported. Objective: The objective of this work was to study the cytotoxic effects of Se-KS on Caco-2, MCF-7 and HepG2 cancer cells. Materials and Methods: Freeze-dried seedlings were ground and incubated in $0.1 \mathrm{M}$ citrate phosphate buffer $\mathrm{pH} 7.0$ for $1 \mathrm{~h}$ at $37^{\circ} \mathrm{C}$ and extracted with dichloromethane to obtain total isothiocyanate (ITC) content which was quantified using the 1,2-benzenedithiole (BDT)-based cyclocondensation assay. The extracts from fresh seedlings were used to determine the cytotoxic effect on Caco2, MCF-7 and HepG2 cancer cells. Results: Se-KS was found to contain total ITC content at $1.02 \mathrm{mmol} / 100 \mathrm{~g}$ dry weight (DW) which was significantly lower than that of 7-day old broccoli microgreens (1.60 mmol/100 g DW) as reference Cruciferous vegetables. In addition, Se-KS extract exhibited cytotoxic effects in a dose- and time-dependent manners. The lowest IC50 value of $82.83 \mu \mathrm{g} / \mathrm{mL}$ at $72 \mathrm{~h}$ was derived from HepG2 cells and the highest IC50 value of $164.00 \mu \mathrm{g} / \mathrm{mL}$ at $72 \mathrm{~h}$ was from MCF-7 cells suggesting that the Se-KS extract was most effective against HepG2 cells. Cancer cells showed signs of apoptotic bodies over $72 \mathrm{~h}$ and DNA fragmentations at $24 \mathrm{~h}$ indicating that the Se-KS extract was able to induce apoptosis in cancer cells in addition to cytotoxic effect. Conclusion: Thus, Se-KS could be a novel source of organo selenium with chemopreventive benefits for functional food development.
\end{abstract}

Key words: Kale, Caco-2, HepG2, Isothiocyanate, MCF-7, Selenium.

\section{INTRODUCTION}

About $10 \%$ of the world's vegetable production is derived from Cruciferae species. ${ }^{1}$ Vegetables in the Cruciferae family are well-known to produce the glucosinolates; S-containing compounds with a plethora of evidence in human health benefits in especially their hydrolysis products called isothiocyanates (ITCs).,3 Mainly, glucosinolates are responsible for plant communicating and signaling pertaining in response to external or environmental stimuli such as plant defense against insects, some food bacteria, and against some fungi. ${ }^{2,3}$ Interestingly, Cruciferous species are able to accumulate Selenium (Se) and synthesize seleno-amino acids, selenoproteins as well as selenoglucosinolates. The breakdown products of selenoglucosinolates such as phenylalkyl isoselenocyanates confer more chemopreventive effects compared to their S-containing analogs. ${ }^{4,5}$ The antioxidant selenoproteins have been presumed to have counter effect against oxidative stress. ${ }^{6}$ Previously, it was shown that consumption of Se-enriched broccoli containing these selenocompounds alongside others may have also a beneficial implication in the human immune response.

In Thailand, Chinese kale (Brassica oleracea var. alboglabra L.) represents the most popular vegetable consumed and belongs to the family of Cruciferae. ${ }^{8}$ Chinese kale can reduce the toxicity of inorganic Se because it transforms inorganic Se to several organic species of Se. ${ }^{8}$ Recently, it has been reported that the highest antioxidant activities of Se-enriched Chinese kale seedlings (Se-KS) were found in seedlings grown on $30 \mathrm{mg} \cdot \mathrm{Se} / \mathrm{L}, 15$ days after germination. ${ }^{8}$ Total Se content and antioxidant activities were strongly correlated suggesting that $\mathrm{Se}$ could enhance antioxidant capacities. In addition, Se-KS did not create any toxicological signs or abnormal pathological changes in the liver, kidney, and heart or mortality in rats. ${ }^{8}$ Therefore, the Se-KS could be an alternative source of organo Se as a novel Se supplementary functional food. However, the cytotoxicity of Se-KS on human cancer cells is yet to be reported. Thus, the objective of this work was to study the cytotoxic effects of Se-KS on Caco-2, MCF7 and HepG2 cancer cells.

\section{MATERIALS AND METHODS}

\section{Cultivation of Se-KS}

Seeds of Chinese kale (Brassica oleracea var. alboglabra L.) were obtained from Chia Tai Company Limited (Thailand). Authentication of the seeds was done by Assoc. Prof. Dr. Anut Chantiratikul from Mahasarakham University using seed morphology checking and cultivation trial in 
prior to this work. Briefly, the Chinese kale seeds were soaked in tap water for $15 \mathrm{~h}$ before planting. After that, the seeds were cultivated on a wet sponge $(35 \times 40 \times 30 \mathrm{~cm})$ at room temperature in the dark for 3 days until the seeds began to germinate. The covers of the plastic pots were released, and the germinated Chinese kale was subjected to light from a fluorescent lamp $(36 \mathrm{~W})$ with a $12 \mathrm{~h}$ dark/light cycle and watered with tap water daily for 4 days as previously described. ${ }^{9}$ Afterwards, the germinated seedlings were cultivated in the adapted modified Hoagland's solution containing $30 \mathrm{mg} \cdot \mathrm{Se} / \mathrm{L}$ in the form of sodium selenite under light intensity of $200 \mu \mathrm{mol} \mathrm{m} \mathrm{mec}^{-1}$ for $12 \mathrm{~h}$ per day. After 15 days of cultivation, the Se-Chinese kale (Se-KS) seedlings were harvested, washed thoroughly with deionized water, freeze-dried, and stored in a freezer at $-20^{\circ} \mathrm{C}$ until analysis. Broccoli microgreens of 7 -day old without Se supplementation were used as reference. Broccoli seeds (Now Foods, USA) were grown according to the modified method of $\mathrm{Wu}$ et al. (2019). ${ }^{10}$ Briefly, broccoli seeds were soaked in distilled water for $8 \mathrm{~h}$ and germinated on vermiculite at $25^{\circ} \mathrm{C}(12 \mathrm{~h}$ light $/ 12$ dark cycle $)$ and were sprayed with $20 \mathrm{~mL}$ of deionized water daily for 7 days till harvested by cutting the shoots above the roots, freeze-dried and stored at $-20^{\circ} \mathrm{C}$.

\section{Quantification of the total ITC content}

ITCs were extracted according to Luang-In et al. (2018). ${ }^{11}$ The freezedried Se-KS $(250 \mathrm{mg})$ or broccoli microgreens $(250 \mathrm{mg})$ were ground in a sterile mortar with $4 \mathrm{~mL}$ of $0.1 \mathrm{M}$ citrate-phosphate buffer ( $\mathrm{pH} 7.0)$ and then the mixture was incubated at $37^{\circ} \mathrm{C}$ for $1 \mathrm{~h}$ with shaking at 250 $\mathrm{rpm}$. Subsequently, dichloromethane (DCM) was added in a ratio of 1:1 to the mixture and incubated at $37^{\circ} \mathrm{C}$ for $30 \mathrm{~min}$ with shaking at $250 \mathrm{rpm}$. The mixture was then centrifuged at $10,000 \mathrm{~g}$ for $15 \mathrm{~min}$ and the lower layer of DCM phase was transferred to mix with $0.5 \mathrm{~g} \mathrm{MgSO}_{4}$ to rid of moisture and centrifuged again for $15 \mathrm{~min}$. The supernatant was diluted with methanol in a ratio of 1:4 and dried using a rotatory evaporator at $40^{\circ} \mathrm{C}$. Quantification of the total ITC content was carried out using the 1,2-benzenedithiole (BDT)-based cyclocondensation assay as previously described by Zhang (2012). ${ }^{12}$ In theory, ITCs react with BDT and are fully converted to 1,3-benzodithiole-2-thione which can be detected at $365 \mathrm{~nm}$ using a spectrophotometer. Briefly, the ITC extract dissolved in methanol $(10 \mu \mathrm{L})$ and methanol $(90 \mu \mathrm{L})$ were added to the 96 -well plate along with $0.1 \mathrm{M}$ phosphate buffer $\mathrm{pH} 8.0(90 \mu \mathrm{L})$ and $0.08 \mathrm{M}$ 1,3-benzodithiole-2-thione $(10 \mu \mathrm{L})$. The 96 -well plate was incubated at $60^{\circ} \mathrm{C}$ for $2 \mathrm{~h}$ prior to measurement at $365 \mathrm{~nm}$ using a microplate reader (M965+, Mastertech, Taiwan). Direct spectrophotometric determination of the reacted solution at $365 \mathrm{~nm}$ allows measurement of as low as $1 \mathrm{nmol}$ of ITC..$^{12}$ The total ITC content was recorded as $\mathrm{mmol} / 100 \mathrm{~g}$ DW when calibrated to the ITC authentic standard, benzyl isothiocyanate (BITC) (Sigma-Aldrich, UK) with triplicate.

\section{ITC extract preparation for cytotoxicity test}

ITCs were extracted similar to the above method (Luang-In et al., $2018)^{11}$, however here fresh seedlings were used. Fresh Se-KS samples $(50 \mathrm{~g})$ were ground and homogenized with $50 \mathrm{~mL}$ of $0.1 \mathrm{M}$ citrate phosphate buffer, $\mathrm{pH} 7.0$ and incubated at $37^{\circ} \mathrm{C}$ for $1 \mathrm{~h}$ at $250 \mathrm{rpm}$ using a shaking incubator (LSI-1005R, LabTech, Korea). Subsequently, DCM was added in a ratio of $1: 1$ to the mixture and incubated at $37^{\circ} \mathrm{C}$ for 30 $\mathrm{min}$ at $250 \mathrm{rpm}$ using a shaking incubator (LSI-1005R, LabTech, Korea). DCM was a suitable solvent since ITCs were weakly polar and DCM led to higher ITC yields than when using ethyl acetate, acetonitrile or water. ${ }^{13}$ The mixture was then centrifuged at $10,000 \mathrm{~g}$ for $15 \mathrm{~min}$ and the lower layer of DCM phase was transferred to mix with $5 \mathrm{~g} \mathrm{MgSO}_{4}$ to rid of moisture and centrifuged again for $15 \mathrm{~min}$ and clear supernatants were dried using a rotatory evaporator at $40^{\circ} \mathrm{C}$.The ITC extract was then dissolved in dimethylsulfoxide (DMSO) at the concentration of 40 $\mathrm{mg} / \mathrm{mL}$ and used as a stock solution and filtered through a $0.22 \mu \mathrm{m}$ for cytotoxicity assay.

\section{Cancer cell cultures}

The human colorectal adenocarcinoma Caco-2 (ATCC ${ }^{*}$ HTB-37 ${ }^{\text {mix }}$ ), human breast adenocarcinoma MCF-7 (ATCC ${ }^{\circ}$ HTB-22 $2^{\text {mox }}$ ) and human hepatocellular carcinoma HepG2 (ATCC ${ }^{\circ} \mathrm{HB}-8065^{\mathrm{mw}}$ ) were obtained from the American Type Culture Collection (ATCC; Manassas, VA, USA). These cancer cells were grown and maintained in Dulbecco's modified Eagle's medium (DMEM, Sigma-Aldrich) ${ }^{14}$ supplemented with $10 \%(\mathrm{v} / \mathrm{v})$ fetal calf serum and $100 \mathrm{U} / \mathrm{mL}$ of penicillin, $100 \mu \mathrm{g} /$ $\mathrm{mL}$ of streptomycin at $37^{\circ} \mathrm{C}$ in an atmosphere of $5 \% \mathrm{CO}_{2} / 95 \%$ air at constant humidity. DMEM media for cell lines cultures were renewed every 2-3 days until $80 \%$ confluency was reached. Cultured cell lines were washed with phosphate-buffered saline (PBS), $\mathrm{pH} 7.2$ before trypsinization with $0.25 \%$ Trypsin-EDTA.

\section{Cytotoxicity on cancer cells}

This was conducted as Buranrat et al. (2017)..$^{14}$ Cancer cells were initially inoculated into a 96 -well plate (at $5 \times 10^{3}$ cells/well). After incubation for $24 \mathrm{~h}$, ITC extract from Se-KS (at a final concentration of $0-250 \mu \mathrm{g} / \mathrm{ml}$ ) were subsequently added to the cancer cells, and then incubated for $24-72 \mathrm{~h}$ and control wells were cancer cells treated with 0.5\% DMSO in media. Thereafter, 3-(4,5-Dimethylthiazol-2-yl)-2,5Diphenyltetrazolium Bromide (MTT) (at a final concentration of 0.5 $\mathrm{mg} / \mathrm{mL}$ ) was added to each well and incubated for an additional $4 \mathrm{~h}$. Culture media were discarded, $200 \mu \mathrm{L}$ of DMSO was added and vibrated for $20 \mathrm{~min}$. Absorbance was measured at $590 \mathrm{~nm}$ using a microplate reader (M965+, Mastertech, Taiwan). Cytotoxicity of ITC extract of Se$\mathrm{KS}$ against cancer cells was measured as $\mathrm{IC}_{50}$ value. When $\%$ cytotoxicity was $\leq 50 \%$, it represented non-cytotoxic effect and when $\%$ cytotoxicity was $>50 \%$, it represented cytotoxic effect. Cell morphology was also observed using an inverted microscope (NIB-100, Xenon, China).

\section{DNA fragmentation analysis}

The cancer cells $\left(2 \times 10^{5}\right.$ cells $\left./ \mathrm{mL}\right)$ were seeded into 6 well plates and incubated at $37^{\circ} \mathrm{C}$ under $5 \% \mathrm{CO}_{2}$ for $24 \mathrm{~h}$. ITC extract of Se-KS ( 250 $\mu \mathrm{g} / \mathrm{mL}$ ) were added and followed the same incubation condition for 48 h. Cells were washed with PBS buffer ( $\mathrm{pH}$ 7.2) and genomic DNA was then extracted using GF-1 Plant DNA Extraction Kit (Vivantis, Malaysia) according to the kit's manual. The extracted DNA $(1 \mu \mathrm{g} / \mathrm{mL})$ was analyzed on gel electrophoresis of $1 \%$ gel containing $3 \mu \mathrm{L} / 100 \mathrm{~mL}$ of SYBR Safe dye (Vivantis, Malaysia). The genomic DNA $(1 \mu \mathrm{g} / \mathrm{mL})$ was mixed with $6 \mathrm{X}$ loading dye in the ratio of 5:3 prior to running on agarose gel electrophoresis at $100 \mathrm{~V}$ for $40 \mathrm{~min}$. DNA maker (100 ng) was used and DNA bands were viewed using gel documentation. ${ }^{14}$

\section{Statistical analysis of data}

Data were collected in triplicate and results were reported as means \pm standard deviation (SD). Statistical analysis was performed using Oneway analysis of variance (ANOVA) and Duncan multiple range's test by the software SPSS (demo version). Statistically significant differences were considered if $p<0.05$.

\section{RESULTS}

\section{Total ITC content in Se-KS}

It is found that the total ITC content of Se-KS was $1.02 \mathrm{mmol} / 100 \mathrm{~g}$ DW which was significantly lower than that of 7-day old broccoli microgreens as Cruciferous vegetable reference (Table 1).

\section{Cytotoxicity of Se-KS extract on cancer cells}

It was found that Se-KS extract had cytotoxic effects on three types of cancer cells; Caco-2, MCF-7 and HepG2 cells in both time- and dosedependent manner (Figure 1). It seems Se-KS extract was least cytotoxic towards MCF-7 cells based on lower cytotoxicity percentage at most 
extract concentrations and at most of the incubation time intervals (Figure 1) when compare to other cancer cell types. In addition, it had the most cytotoxic capacity towards HepG2 cells (Figure 1).These results were in accordance with the calculated IC50 values of Se-KS extract on cancer cells.

It was shown that the lowest IC50 values at all incubation time intervals were derived from HepG2 cells (Table 2) and the highest IC50 values were from MCF-7 cells. The IC50 values were also dependent upon the incubation times. That means the longer time Se-KS extract was in contact with cancer cells, the more cytotoxic effects were observed (Table 2).

\section{Apoptosis in cancer cells}

Apoptosis, is an active, gene regulated form of programmed cell death that is distinct from cell necrosis regarding its morphology, biochemistry, pharmacology and biological significance. Several types of mammalian cells undergo apoptosis during normal development or in response to a plethora of stimuli, including growth factor deprivation, DNA damage, and abnormal expression of oncogene or tumor suppressor genes. ${ }^{15}$ Apoptosis is a widely accepted, important mechanism that contributes to cell growth reduction. ${ }^{16}$ The present study was undertaken to explore whether Se-KS induces apoptosis in three types of cancer cell lines. Apparently, the Se-KS extract in this work was able to induce apoptosis leading to cancer cell death as detected by characteristics of apoptotic bodies in increased concentrations of Se-KS extract over 24, 24 and 72 h (Figures 2-4).

\section{DNA fragmentation analysis}

To elucidate whether the Se-KS extract $(250 \mu \mathrm{g} / \mathrm{mL})$ inhibits cancer cell proliferation through induction of apoptosis; the cell death by DNA fragmentation at $24 \mathrm{~h}$ was examined. It was revealed that the Se-KS extract $(250 \mu \mathrm{g} / \mathrm{mL})$ was optimum enough to induce fragmentation in Caco-2, MCF-7 and HepG2 cells as observed by initial signs of
DNA ladder patterns (Figure 5) when compared to intact DNA in the untreated cells as negative controls.

\section{DISCUSSION}

Cruciferous plants are well-known as rich sources of glucosinolates and thus ITCs. The previous work showed that mature broccoli had the mean total ITC content of $38.6 \mu \mathrm{mol} / 100 \mathrm{~g}$ fresh weight (FW) across Singapore ${ }^{17}$ while mature kale had much lower amount at 18.2 $\mu \mathrm{mol} / 100 \mathrm{~g} \mathrm{FW}$ across $\mathrm{USA}^{18}$ which were lower than the total ITC contents found in our broccoli microgreens and Se-KS suggesting that microgreens are richer in ITCs than mature plants. In addition, it was found that white cabbage sprouts (Brassica oleracea var. capitata) had the total ITC content of $0.25 \pm 0.03 \mu \mathrm{mol} / \mathrm{g}$ DW, Brussel sprouts (B. oleracea var. gemmifera) had $0.37 \pm 0.02 \mu \mathrm{mol} / \mathrm{g} \mathrm{DW}$ and radish (Raphanus sativus var. sativus) had the highest $9.67 \pm 0.03 \mu \mathrm{mol} / \mathrm{g}$ $\mathrm{DW}^{19}$ which were all lower than the total ITC content found in our broccoli microgreens and Se-KS suggesting that total ITC content varied amongst Cruciferous plant microgreens. The total ITC content was a correlation to the total glucosinolates present in these plants and once they were crushed, endogenous plant myrosinase was released to hydrolyze glucosinolates to ITCs. ${ }^{20}$ That means higher ITC content may be due to higher glucosinolate content in the plants.

In similar work, mature Chinese kale leaf extract at $50 \mu \mathrm{g} / \mathrm{mL}$ and $500 \mu \mathrm{g} / \mathrm{mL}$ was found to reach cell viability of A549 alveolar basal epithelial cells at $57 \%$ and $59 \%$ of the untreated control ${ }^{21}$ indicating that Chinese kale extracts exhibit moderate cell growth inhibition, ca. $60-70 \%$ cell survival at $500 \mu \mathrm{g} / \mathrm{mL}$. Compared to our findings, SeKS extract at $150 \mu \mathrm{g} / \mathrm{mL}$ was able to reach $c a$. $60 \%$ cytotoxicity $(40 \%$ cell survival) towards Caco- 2 cells at $72 \mathrm{~h}, \mathrm{ca}$. 50\% cytotoxicity $(50 \%$ cell survival) towards MCF-7 cells and ca. $80 \%$ cytotoxicity (20\% cell survival) towards HepG2 cells (Figure 1) suggesting Se-KS extracts were more effective towards cancer cells than mature Chinese kale leaf extract. We hypothesized that Se-KS had greater content of GSLs and thus the corresponding ITCs than mature counterparts and thus

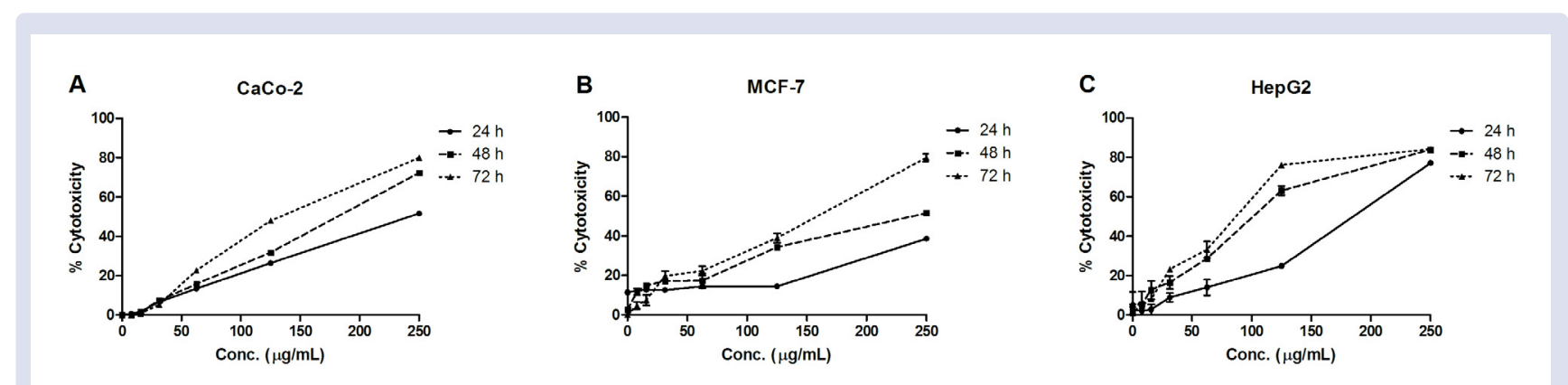

Figure 1: Cytotoxicity of Se-KS extract on cancer cells. (A) Caco-2 cells. (B) MCF-7 cells. (C) HepG2 cells.

Table 1: Total ITC content of selenium-enriched Chinese kale.

\begin{tabular}{cc}
\hline Sample & Total ITC content (mmol/100 g DW) \\
\hline Selenium-enriched Chinese kale & $1.02 \pm 0.10^{\mathrm{B}}$ \\
Broccoli microgreen & $1.60 \pm 0.10^{\mathrm{A}}$ \\
\hline
\end{tabular}

Capital letters indicate statistical differences in the column $(p<0.05)$.

Table 2: IC50 values of selenium-enriched Chinese kale extract against cancer cells.

\begin{tabular}{ccccc}
\hline & & \multicolumn{3}{c}{ IC $_{50}(\mu \mathrm{g} / \mathrm{mL})$} \\
Sample & Time $(\mathbf{h})$ & Caco-2 & MCF-7 & HepG2 \\
\hline Se-KS & 24 & $345.60 \pm 10.71^{\mathrm{Cb}}$ & $345.60 \pm 10.71^{\mathrm{Cb}}$ & $178.27 \pm 0.91^{\mathrm{Ca}}$ \\
& 48 & $234.92 \pm 4.09^{\mathrm{Bb}}$ & $234.92 \pm 4.09^{\mathrm{Bb}}$ & $100.56 \pm 3.11^{\mathrm{Ba}}$ \\
& 72 & $151.33 \pm 1.76^{\mathrm{Ab}}$ & $164.00 \pm 7.39^{\mathrm{Ac}}$ & $82.83 \pm 2.92^{\mathrm{Aa}}$ \\
\hline
\end{tabular}

Capital letters and small letters indicate statistical differences in the column and rows $(p<0.05)$, respectively. 


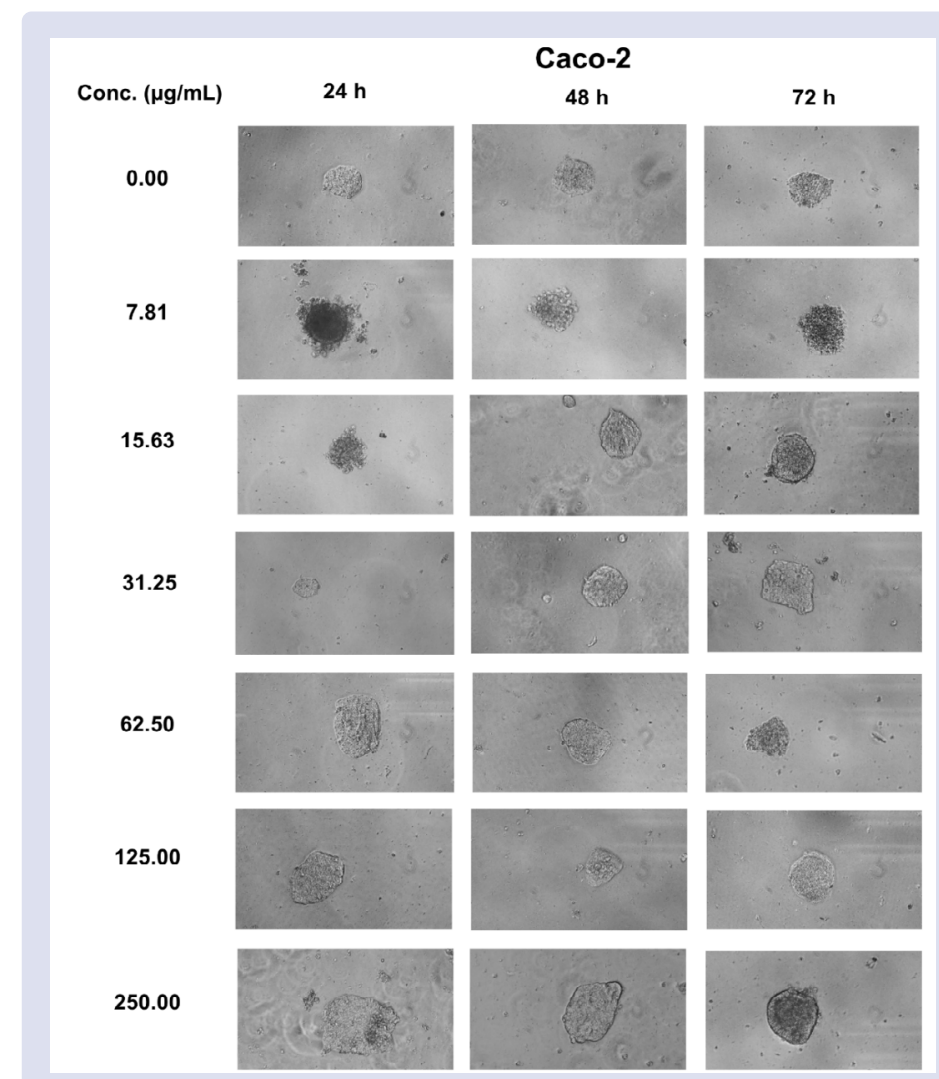

Figure 2: Cell morphology of Caco-2 cells after incubation with various concentrations of Se-KS extracts over 24,48 and $72 \mathrm{~h}$.

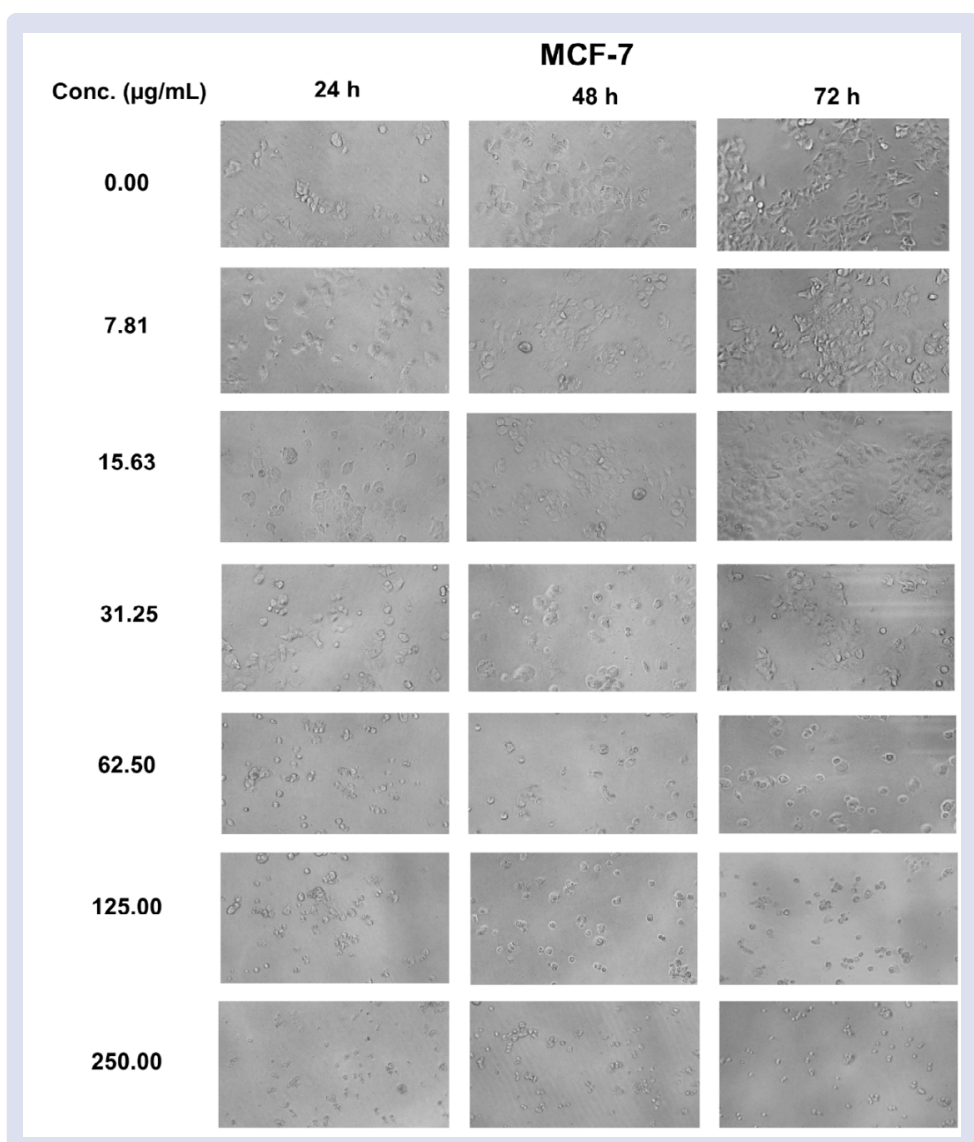

Figure 3: Cell morphology of MCF-7 cells after incubation with various concentrations of Se-KS extracts over 24,48 and $72 \mathrm{~h}$. 


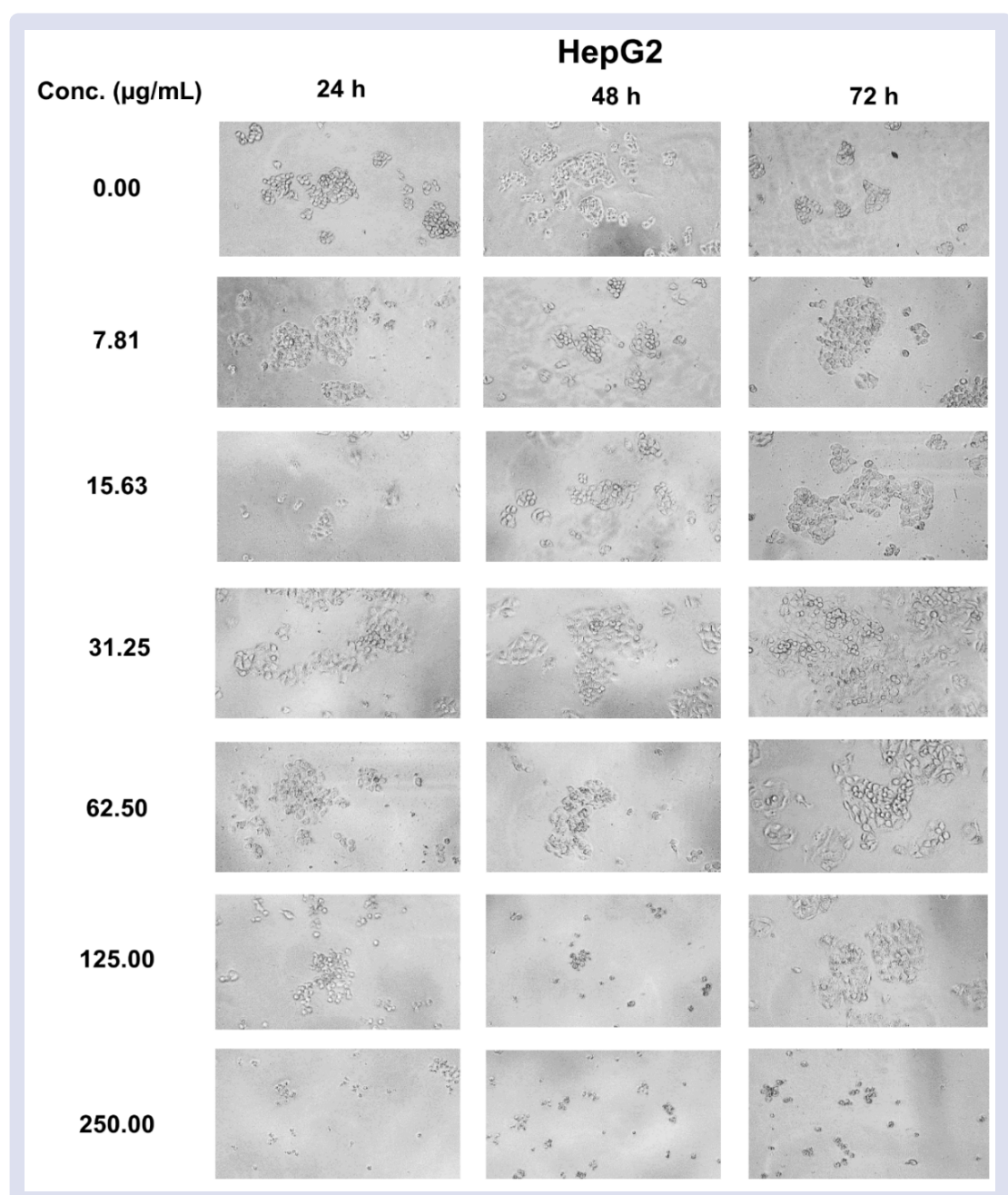

Figure 4: Cell morphology of HepG2 cells after incubation with various concentrations of SeKS extracts over 24,48 and $72 \mathrm{~h}$.

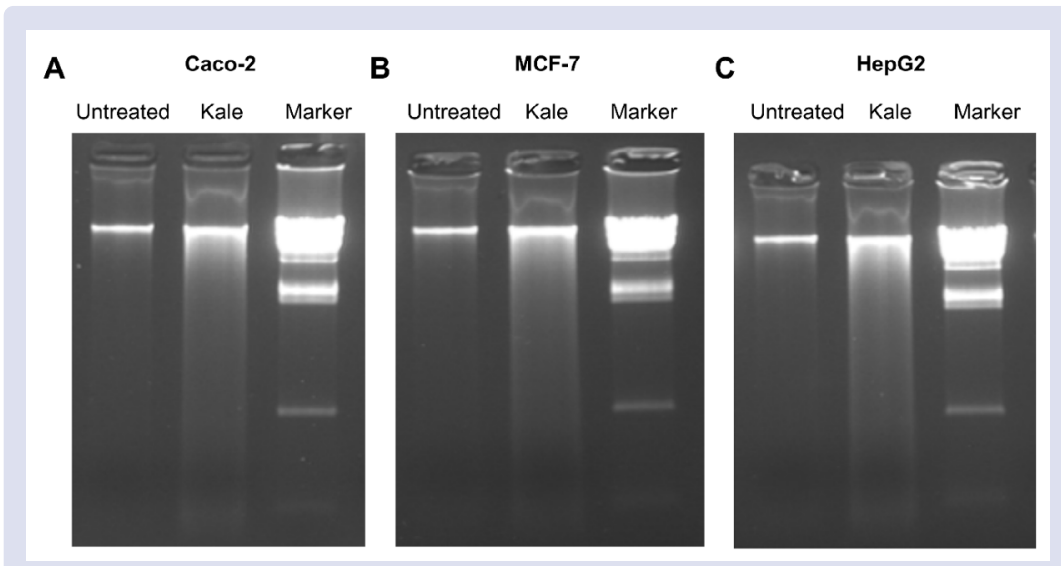

Figure 5: DNA fragmentation of cancer cells by Se-KS extract $(250 \mu \mathrm{g} / \mathrm{mL})$ incubated for $24 \mathrm{~h}$ on agarose gel electrophoresis. (A) Caco-2 cells. (B) MCF-7 cells. (C) HepG2 cells.

Se-KS extracts showed higher cytotoxic effect than mature Chinese kale extract. Our hypothesis was supported by the previous reports. The total glucosinolate content was significantly decreased in mature leaves. ${ }^{22}$ The concentration of sulforaphane in broccoli sprouts $(1,153$ $\mathrm{mg} / 100 \mathrm{~g} \mathrm{DW})$ is about 10 times greater than mature broccoli (44-171 $\mathrm{mg} / 100 \mathrm{~g} \mathrm{DW}) .^{23}$
It was well-known that abiotic stress, such as supplementation of Se to plants, can lead to increased production of phenolic compounds. ${ }^{24}$, but the mechanism is still not fully understood. It is hypothesized that the Se enhances accumulation of glucose which is an important substrate in many metabolic pathways. ${ }^{25}$ Likewise, the previous work showed that total phenolic content in Se-KS was significantly higher than that in regular Chinese kale seedlings (R-KS) $(30.1 \pm 0.1 \mathrm{mg} \mathrm{GE} / \mathrm{g} \mathrm{DW}$ vs. 
$18.5 \pm 0.7 \mathrm{mg} \mathrm{GE} / \mathrm{g} \mathrm{DW}){ }^{8}$ Similarly, broccoli seedlings with Se were shown to have lower GI50 value (concentration that produces $0 \%$ cell growth or totally cytostatic effect) at $68.1 \mu \mathrm{g} / \mathrm{mL}$ against MCF-7 cells than that of broccoli seedlings without Se $(94.6 \mu \mathrm{g} / \mathrm{mL}) .{ }^{26}$ However, broccoli seedlings with selenium in the previous work seem to be more cytotoxic towards MCF-7 cells than our Se-KS with IC50 value of $164 \mu \mathrm{g} / \mathrm{mL}$ (Table 2). This was the first report of the effect of SeKS extract on DNA fragmentation in cancer cells. In literature, it was found that sulforaphane at $5 \mu \mathrm{M}$ induced partial internucleosomal DNA fragmentation in MCF-7 cells ${ }^{27}$ similar to the effect of $250 \mu \mathrm{g} / \mathrm{mL}$ Se-KS extract in this work.

\section{CONCLUSION}

It was suggested that the Se-KS extract may be efficacious in treating Caco-2, MCF-7 and HepG2 cancer cells. However, further research will be required to fully delineate the part it plays in cancer and its molecular mechanism, which is not yet clearly understood. Se-KS appears to have potential as a chemopreventive functional food.

\section{ACKNOWLEDGEMENTS}

This research was funded by Mahasarakham University, Thailand (Fast Track 2020). Authors would like to thank Department of Biotechnology, Mahasarakham University, Thailand for laboratory facilities.

\section{CONFLICTS OF INTEREST}

The authors declare no conflicts of interest.

\section{REFERENCES}

1. Augustine R, Arya GC, Nambiar DM, Kumar R, Bisht NC. Translational genomics in Brassica crops: challenges, progress, and future prospects. Plant Biotechnol Rep. 2014;8:65-81.

2. Lippmann D, Lehmann C, Florian S, Barknowitz G, Haack M, Mewis I, et al. Glucosinolates from pak choi and broccoli induce enzymes and inhibit inflammation and colon cancer differently. Food Funct. 2014;5:1073-81.

3. Guzmán-Pérez V, Bumke-Vogt C, Schreiner M, Mewis I, Borchert A, Pfeiffer AF. Benzylglucosinolate derived isothiocyanate from Tropaeolum majus reduces gluconeogenic gene and protein expression in human cells. PLoS One. 2016;11:e0162397.

4. Sharma AK, Sharma A, Desai D, Madhunapantula SV, Huh SJ, Robertson GP, et al. Synthesis and anticancer activity comparison of phenylalkyl isoselenocyanates with corresponding naturally occurring and synthetic isothiocyanates. J Med Chem. 2008;51:7820-6

5. Emmert SW, Desai D, Amin S, Richie JP Jr. Enhanced Nrf2-dependent induction of glutathione in mouse embryonic fibroblasts by isoselenocyanate analog of sulforaphane. Bioorg Med Chem Lett. 2010;20:2675-9.

6. Rayman MP, Infante HG, Sargent M. Food-chain selenium and human health: spotlight on speciation. Br J Nutr. 2008;100:238-53.

7. Bentley-Hewitt KL, Chen RKY, Lill RE, Hedderley DI, Herath TD, Matich AJ, et al. Consumption of selenium-enriched broccoli increases cytokine production in human peripheral blood mononuclear cells stimulated ex vivo, a preliminary human intervention study. Mol Nutr Food Res. 2014;58:2350-7.

8. Leamsamrong K, Tongjaroenbuangam W, Maneetong S, Chantiratikul A, Chinrasri O, Chantiratikul P. Physicochemical contents, antioxidant activities, and acute toxicity assessment of selenium-enriched Chinese kale (Brassica oleracea var. alboglabra L.) seedlings. J Chem. 2019;7983038:1-12.

9. Maneetong S, Chookhampaeng S, Chantiratikul A, Chinrasri O, Thosaikham W, Sittipout $\mathrm{R}$, et al. Hydroponic cultivation of selenium-enriched kale (Brassica oleracea var. alboglabra L.) seedling and speciation of selenium with HPLC-ICPMS. Microchem J. 2013;108:87-91.

10. Wu L, Huo W, Yao D, Li M. Effects of solid matrix priming (SMP) and salt stress on broccoli and cauliflower seed germination and early seedling growth. Sci Hortic. 2019; 255:161-8.

11. Luang-In V, Deeseenthum S, Udomwong P, SaenghaW, Gregori M. Formation of sulforaphane and iberin products from Thai cabbage fermented by myrosinasepositive bacteria. Molecules. 2018;23:3-5.

12. Zhang $Y$. The 1,2-benzenedithiole-based cyclocondensation assay: a valuable tool for the measurement of chemopreventive isothiocyanates. Crit Rev Food Sci Nutr. 2012;52:525-32.

13. Han D, Row KH. Separation and purification of sulforaphane from broccoli by solid phase extraction. Int J Mol Sci. 2011;12:1854-61.

14. Buranrat B, Mairuae N, Konsue A. Cratoxy Formosum leaf extract inhibits proliferation and migration of human breast cancer MCF-7 cells. Biomed Pharmacother. 2017;90:77-84

15. Vaux DL, Strasser A. The molecular biology of apoptosis. PNAS.1996;93:2239 44.

16. Bakshi H, Smitha S, Manik S. Assessment of cytotoxic and apoptogenic activity of Crocus sativus on human cancer cell lines. Ind J Appl Life Sci. 2008;4:34-8.

17. Jiao D, Yu MC, Hankin JH, Low SH, Chung FL. Total isothiocyanate contents in cooked vegetables frequently consumed in Singapore. J Agric Food Chem. 1998;46:1055-8

18. Shapiro TA, Fahey JW, Wade KL, Stephenson KK, Talalay P. Human metabolism and excretion of cancer chemoprotective glucosinolates and isothiocyanates of cruciferous vegetables. Cancer Epidemiol Biomarkers Prev. 1998;7:1091-100.

19. Kołodziejski D, Piekarska A, Hanschen FS, Pilipczuk T, Tietz F, Kusznierewicz, et al. Relationship between conversion rate of glucosinolates to isothiocyanates/ indoles and genotoxicity of individual parts of Brassica vegetables. Eur Food Res Technol. 2019;245:383.

20. Fahey JW, Zalcmann AT, Talalay P. The chemical diversity and distribution of glucosinolates and isothiocyanates among plants. Phytochem. 2001;56:5-51.

21. Farag MA, Abdel Motaal AA. Sulforaphane composition, cytotoxic and antioxidant activity of crucifer vegetables. J Adv Res. 2010;1:65-70.

22. Jiang D, Lei J, Cao B, Wu S, Chen G, Chen C. Molecular cloning and characterization of three glucosinolate transporter (GTR) genes from Chinese kale. Genes. 2019;10:202.

23. Sanlier N, GulerSaban M. The benefits of Brassica vegetables on human health J Human Health Res.2018;1:104.

24. Dutta RJ, Maharia RS. Antioxidant responses of some common medicinal plants grown in copper mining areas. Food Chem. 2012;131:259-65.

25. Lei C, Ma Q, Tang QY, Ai XR, Zhou Z, Yao L, et al. Sodium selenite regulates phenolics accumulation and tuber development of purple potatoes. Sci Hortic. 2014;165:142-7.

26. Bachiega P, Salgado JM, de Carvalho JE, Ruiz ALT, Schwarz K, Tezotto T, et al. Antioxidant and antiproliferative activities in different maturation stages of broccoli (Brassica oleracealtalica) biofortified with selenium. Food Chem. 2016;190:771-6.

27. Pledgie-Tracy A, Sobolewski MD, Davidson NE. Sulforaphane induces cell type-specific apoptosis in human breast cancer cell lines. Mol Cancer Ther. 2007;6:1013-21. 


\section{GRAPHICAL ABSTRACT}

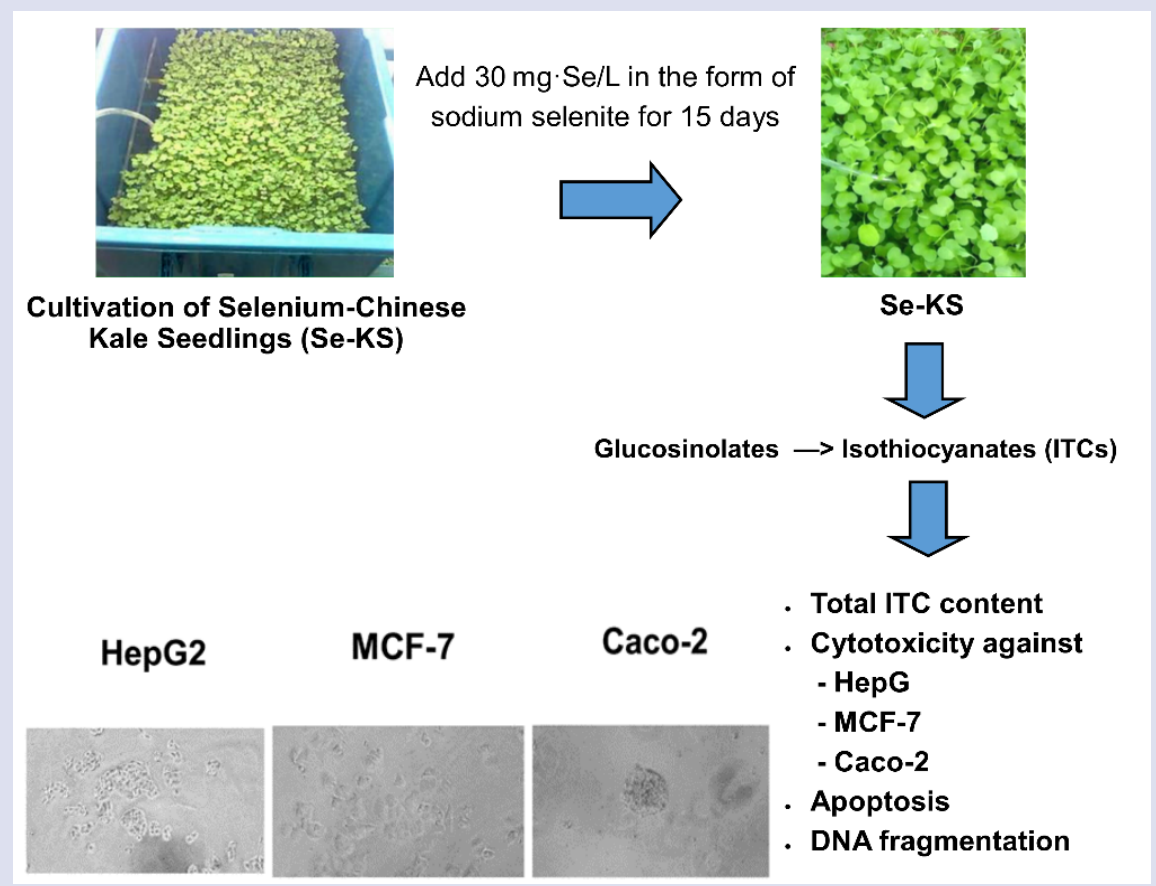

\section{ABOUT AUTHORS}

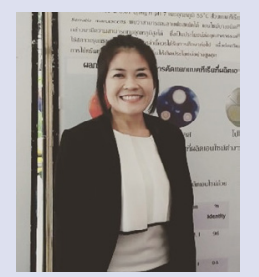

Asst. Prof. Dr. Vijitra Luang-In: Finished her PhD degree in Microbiology \& Biochemistry, from Imperial College, London. At present, she is an Assistant Professor in Department of Biotechnology, Faculty of Technology, Mahasarakham University, Thailand. She works on glucosinolates, isothiocyanates and microbial applications.

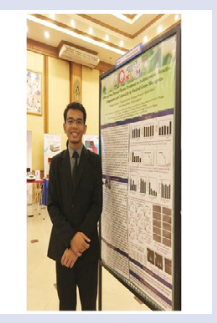

Mr. Worachot Saengha: Obtained his BSc Biotechnology degree in 2017 from Mahasarakham University, Thailand. Currently, he is about to complete his MSc Biotechnology degree at Department of Biotechnology, Faculty of Technology, Mahasarakham University, Thailand. His research project focused on plant biochemistry, cancer biology and natural product from plants.

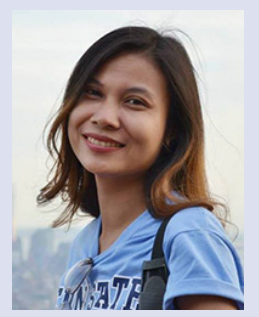

Assoc. Prof. Dr. Benjaporn Buranrat: She obtained her MSc and PhD degrees in Pharmacology from Khonkaen University, Thailand. She is currently working as Associate Professor at Faculty of Medicine, Mahasarakham University, Thailand. Her research focuses on cancer treatment, carcinogenesis, and pharmacogenomics.

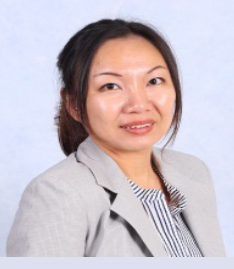

Assoc. Prof. Dr. Nyuk Ling Ma: She obtained her PhD in Cell and Molecular Biology from Imperial College London, UK. She is currently working as Associate Professor at Faculty of Science and Marine Environment, Universiti Malaysia Terengganu, Malaysia. Her research focuses on plant environment signaling, plant tissue culture and omics technology. 
Assoc. Prof. Dr. Anut Chantiratikul: He obtained his PhD degree in Animal nutrition from Universiti Putra Malaysia, Malaysia. Currently, he is working as Associate Professor at Faculty of Technology, Mahasarakham University, Thailand. His research project focuses on selenium in animal nutrition.

Cite this article: Luang-In V, Saengha W, Buranrat B, Chantiratikul A, Ma NL. Cytotoxicity of Selenium-Enriched Chinese Kale (Brassica oleracea var. alboglabra L.) Seedlings Against Caco-2, MCF-7 and HepG2 Cancer Cells. Pharmacogn J. 2020;12(4):674-81. 